\title{
Pharmacology of Ficus religiosa- A review
}

\author{
Prof Dr Ali Esmail Al-Snafi \\ Department of Pharmacology, College of Medicine, Thi qar University, Iraq
}

\begin{abstract}
Chemical analysis showed that Ficus religiosa contained tannins, phenols, saponins, sugars, alkaloids, methionine, terpenoids, flavonoids, glycosides, proteins, separated amino acids, essential and volatile oils and steroids. Previous pharmacological studies revealed that Ficus religiosa possessed antimicrobial, anti-parasitic, anti-Parkinson's, anticonvulsant, anti-amnesic, anticholinergic, antidiabetic, antiinflammatory, analgesic, cytotoxic, anti-ulcer, wound healing, antioxidant, anti- asthmatic, reproductive, hepato-, nephro- and dermato- protective effects. The current review highlights the chemical constituents and pharmacological effects of Ficus religiosa.
\end{abstract}

Keywords: chemical constituents, pharmacological effects, pharmacology, Ficus religiosa

\section{INTRODUCTION:}

Herbal medicine is the oldest form of medicine known to mankind. It was the mainstay of many early civilizations and still the most widely practiced form of medicine in the world today. The World Health Organization (WHO) estimates that 4 billion people, 80 percent of the world population, presently use herbal medicine for some aspect of primary health care[1]. Plants generally produce many secondary metabolites which are bio-synthetically derived from primary metabolites and constitute an important source of many pharmaceutical drugs [2-50]. Ficus religiosa contained tannins, phenols, saponins, sugars, alkaloids, methionine, terpenoids, flavonoids, glycosides, proteins, separated amino acids, essential and volatile oils and steroids. Previous pharmacological studies revealed that Ficus religiosa possessed antimicrobial, anti-parasitic, anti-Parkinson's, anticonvulsant, anti-amnesic, anticholinergic, antidiabetic, antiinflammatory, analgesic, cytotoxic, anti-ulcer, wound healing, antioxidant, anti- asthmatic, reproductive, hepato-, nephro- and dermato- protective effects. This review will highlight the chemical constituents and pharmacological effects of Ficus religiosa

Synonyms:

Ficus caudata Stokes, Ficus peepul Griff., Ficus religiosa var. cordata Miq., Ficus religiosa var. rhynchophylla Miq., Ficus rhynchophylla Steud., Ficus superstitiosa Link, Urostigma affine Miq. and Urostigma religiosum (L.) Gasp [51].

II.

TAXONOMIC CLASSIFICATION:

Kingdom: Plantae, Subkingdom: Viridaeplantae, Phylum: Tracheophyta, Subphylum: Euphyllophytina, Infraphylum: Radiatopses, Class: Magnoliopsida, Subclass: Dilleniidae, Superorder: Urticanae, Order: Urticales, Family: Moraceae, Genus: Ficus, Species Ficus religiosa [52].

III. COMMON NAMES:

Arabic: teen mukadas, teen Asnam, shajarat bebal, Ficus abu lesan; Chinese: pu ti shu; English: botree, peepultree, sacred fig; French: arbre de Dieu, figuier de pagodes; German: bobaum, heiliger feigenbaum, indischer pepulbaum, pepulbaum; India: papal, pipul; Italian: fico del diavolo; Portuguese: figueira-dospagodes, figueira-religiosa; Spanish: higuera de agua; Swedish: tempelfikus [53].

\section{DISTRIBUTION:}

It is native to the Asia-Tropical (Bangladesh; India, Nepal, Pakistan, China, Myanmar, Thailand, Vietnam and Iraq) and it is cultivated in wide tropical areas [53].

\section{DESCRIPTION:}

Trees, 15-25 m tall, d.b.h. 30-50 cm, epiphytic when young, crown wide when mature. Bark gray, smooth or longitudinally \pm fissured. Branchlets grayish brown, sparsely pubescent when young. Stipules ovate, small, apex acute. Petiole slender, as long as or longer than leaf blade, articulate; leaf blade triangular-ovate, 9-17 $\times 8-12 \mathrm{~cm}$, leathery, abaxially green, adaxially dark green and shiny, base broadly cuneate to \pm cordate, margin entire or undulate, apex acute to caudate with a $2-5 \mathrm{~cm}$ cauda; basal lateral veins 2, secondary veins 5-7 on each side of midvein. Figs axillary on leafy branchlets, paired or solitary, red when mature, globose to depressed globose, 1-1.5 $\mathrm{cm}$ in diam., smooth; peduncle 4-9 mm; involucral bracts ovate. Male, gall, and female flowers within same fig. 
Male flowers: few, near apical pore, sessile; calyx 2- or 3-lobed, margin revolute; stamen 1; filament short. Gall flowers: pedicellate; calyx 3- or 4-lobed; ovary globose, smooth; style short; stigma enlarged, 2-lobed. Female flowers: sessile; calyx 4-lobed, broadly lanceolate; ovary globose, smooth; style thin; stigma narrow [54].

\section{Traditional uses:}

Traditionally, the leaf juice was used in the treatment of asthma, cough, sexual disorders, diarrhoea, haematuria, ear-ache, toothache, migraine, eye troubles, gastric problems and scabies. The leaf decoction was used as in toothache. The fruits was used in the treatment of asthma and other respiratory disorders and scabies. The stem bark was used in gonorrhea, bleeding, paralysis, diabetes, diarrhea, bone fracture, as antiseptic, astringent and antidote [52].

\section{Physicochemical characteristics:}

Physicochemical analysis of Ficus religiosa fruit powder showed: loss on drying 8.99\%, total ash 5.88\%, acid insoluble ash $0.60 \%$, water soluble $33.10 \%$ and alcohol soluble extractive $28.80 \%$ [55].

\section{Chemical constituents:}

The preliminary phytochemical analysis revealed that the plant contained tannins, phenols, saponins, sugars, alkaloids, methionine, terpenoids, flavonoids, glycosides and steroids [56-61].The total phenol content present in one milligram of aqueous and ethanolic extracts of the bark was 497.77 and $375.23 \mu$ g, respectively [62]. The total phenolic contents of absolute ethanol, absolute methanol, aqueous ethanol (ethanol: water, 80:20 v/v) and aqueous methanol (methanol: water, 80:20 v/v) extracts was $3.13 \pm 0.19,5.34 \pm 0.36,2.67 \pm 0.16$ and $4.11 \pm$ $0.18(\mathrm{GAE} g / 100 \mathrm{~g}$ of $\mathrm{DW}) \quad$ by shaking extraction technique and $2.12 \pm 0.09,4.93 \pm 0.28,2.26 \pm 0.10$ and 4.13 \pm 0.21 (GAE g/100 g of DW) by reflux extraction technique respectively [63]. However, chemical analysis showed that Ficus religiosa was rich in flavonoids, quercetin was most abundant $1.428 \pm 0.5-4.29 \pm 0.4 \mathrm{mg} / \mathrm{Kg}$ and myricetin was also present in good amounts $0.08 \pm 0.3-1.0 \pm 0.5 \mathrm{mg} / \mathrm{kg}$ [64].The barks of Ficus religiosa contained bergapten, bergaptol, lanosterol, $\beta$-sitosterol, stigmasterol, lupen-3-one, $\beta$-sitosterol-d-glucoside (phytosterolin), vitamin k1, tannin, wax, saponin, leucoanthocyanidin, leucoanthocyanin, leucocyanidin-3-0- $\beta$-Dglucopyrancoside, leucopelargonidin- 3-0- $\beta$-D-glucopyranoside, leucopelargonidin-3-0- $\alpha$-L- rhamnopyranoside, lupeol, ceryl behenate, lupeol acetate and $\alpha$-amyrin acetate [65-69].Fruits contained protein 4.9\%, amino acids, isoleucine, phenylalanine, asgaragine, tyrosine, flavonols (kaempeferol, quercetin, and myricetin), undecane, tridecane, tetradecane, (e)- $\beta$-ocimene, $\alpha$ - thujene, $\alpha$-pinene, $\beta$-pinene, $\alpha$-terpinene, limonene, dendrolasine, dendrolasine $\alpha$-ylangene, $\alpha$-copaene, $\beta$-bourbonene, $\beta$-caryophyllene, $\alpha$-trans bergamotene, aromadendrene, $\alpha$ humulene, alloaromadendrene, germacrene, bicyclogermacrene, $\gamma$-cadinene and $\delta$-cadinene 65, 67, 70-71].

The major components of Ficus religiosa leaf oil were identified to be Eugenol (27.0\%), Itaconic anhydride (15.4\%), 3-Methylcyclopenetane-1,2-dione (10.8\%), 2-Phenylethyl alcohol (8.0\%), and Benzyl alcohol (4.2\%). However, the leaf contained 44 compounds including (\%): (3Z)-Hexenol 1.1, (2Z)-Hexenol 0.7, $n$-Hexanol 0.7, Phenol 0.7, Adipoin 0.6, 3-Methylcyclopenetane-1,2-dione 10.8, Itaconic anhydride 15.4, Benzyl alcohol 4.2, Salicylaldehyde 1.5, Phenylacetaldehyde 0.6, Allyl caproate 3.5, Linalool 0.3, n-Nonanal 0.3, 2-Phenylethyl alcohol 8.0, Benzeneacetonitrile 1.2, (2E,6Z)-Nonadienal 0.4, (2E)-Nonen-1-ol 0.5, (2E,6Z)-Nonadienol 0.5, $(E)$-Linalool oxide 0.5, Catechol 1.1, Coumaran 3.4, (E)-Cinnamyl alcohol 0.6, p-Vinylguaiacol 1.1, (3Z)Hexenyl tiglate 0.6, Eugenol 27.6, (2E)-Hexenyl (3Z)-hexenoate 0.3, (E)- $\beta$-Ionone 1.6, Dihydroactinidiolide 0.4, $\alpha$-Copaene-11-ol 0.4, (3Z)-Hexenyl benzoate 0.5, epi- $\gamma$-Eudesmol 0.5, $\gamma$-Eudesmol 0.4, epi- $\alpha$-Cadinol 1.0, $\beta$-Eudesmol 1.8, $\alpha$-Eudesmol 1.0, $\alpha$-Cadinol 0.7, Pentadecanal 0.7, Palmitic acid 0.7 and Phytol 0.7\% [72].

Leaves also contained aspartic acid, glycine, threonine, alanine, proline, tryptophan, tryosine, methionine, valine, isoleucine, leucine, n-nonacosane, n-hentricontanen, hexa-cosanol and n-octacosan 73-74]. HPLC analysis of the methanolic extract showed the presence of high amounts of serotonin $(2.89 \%$, w/w) [75].A serine protease (religiosin) was purified from the decolorized latex of Ficus religiosa. It was a glycoprotein with a molecular mass of $43.4 \mathrm{kDa}$ by MALDI-TOF [76].

\section{Pharmacological effects: Antimicrobial effect:}

Ethanol extracts of the Ficus religiosa was screened for antibacterial activity against Enterococcus faecalis, Proteus vulgaris, Staphylococcus saprophyticus, Shigella flexneri, Shigella sonnie and Shigella dysenteriae. The minimum inhibitory concentrations against these bacteria were within the range of 250$500 \mu \mathrm{g} / \mathrm{ml}$ [77]. The MIC of Ficus religiosa leaves ethanolic extract against ampicillin and vancomycin resistant native strain of Staphylococcus aureus was $3.91 \pm 0.43 \mathrm{mg} / \mathrm{ml}$ [78].The various solvents extract like aqueous, methanol, chloroform, petroleum ether and hexane of the bark of Ficus religiosa were screened for antibacterial activity against Enterotoxigenic E. coli isolated from diarrhoeal patients, at $200 \mathrm{mg} / \mathrm{ml}$ concentration by disc diffusion method. The methanol extracts exhibited good activity compared to chloroform and aqueous extracts. Petroleum ether and hexane extracts did not show any activity[79]. 
A combination of hot alcoholic extracts of Ficus infectoria, Ficus religiosa and Piper betel were found to be effective against resistant and sensitive strains (Gram negative resistant Klebsiella strains, sensitive Klebsiella strains, resistant Enterobacter strains, sensitive Enterobacter strains, resistant Escherichia coli strains, resistant Pseudomonas strains, sensitive Pseudomonas aeruginosa strains and tandard Pseudomonas aeruginosa ATCC 2862) and (Gram positive resistant Staphylococcus strains, sensitive Staphylococcus strains, resistant Micrococcus strain and standard Staphylococcus aureus ATCC 2901), isolated from skin and soft tissue infections. The combined extract was formulated in different ointment bases. The ointment showed bactericidal activity within $2 \mathrm{~h}$ against the resistant strain of Pseudomonas spp [80].Effect of ethanolic extract of Ficus religiosa fruits extract was studied against two Gram positive bacteria (Staphylococcus epidermidis and Staphylococcus aureus) and two Gram negative bacteria (P. vulgaris and Klebsiella pneumonia). The minimum inhibitory concentration of extract against Staphylococcus epidermidis and Klebsiella pneumonia was $15 \mathrm{mg} / \mathrm{ml}$, while the minimum inhibitory concentration against Staphylococcus aureus and P. vulgaris was $30 \mathrm{mg} / \mathrm{ml}$. At $15 \mathrm{mg} / \mathrm{ml}$ concentration of extract $K$. pneumonia showed more sensitivity $(21 \mathrm{~mm})$ than $S$. epidermidis $(19 \mathrm{~mm})$. At $30 \mathrm{mg} / \mathrm{ml}$ concentration $P$. vulgaris showed more sensitivity $(12 \mathrm{~mm})$ than $S$. aureus $(9 \mathrm{~mm})$ [81]. Bark of Ficus religiosa was dissolved in $67 \%$ ethanol. Extract was then subjected to antimicrobial efficacy tests against primary plaque colonizers and periodontal pathogens. Ficus religiosa showed antibacterial activity against primary plaque colonizers at $48 \mathrm{~h}$ with mean zone of inhibition of $2.6 \pm 0.54 \mathrm{~mm}$ [82]. The antimicrobial activity of methanol and diethyl ether extracts of bark and leaves of Ficus religiosa (100, 200, 300 and $400 \mathrm{mg} / \mathrm{ml})$ was investigated against two Gram negative bacteria (E.coli and Pseudomonas aeruginosa), and one Gram positive bacteria (Staphylococcus aureus). The methanol extracts of leaves and bark showed antimicrobial activity, a higher activity was recorded at 400 $\mathrm{mg} / \mathrm{ml}$ concentration against the three tested bacteria. Both leaf and bark methanol extracts gave zone of inhibition of 2.8 and $2.2 \mathrm{~mm}$ against $S$. aureus, 2.4 and $1.8 \mathrm{~mm}$ against E. coli and 2.2 and $1.1 \mathrm{~mm}$ against P.aeroginosa respectively [83].The antimicrobial activity of the aqueous extract of bark leaf, stem, fruit of Ficus religiosa was determined by disc diffusion method against Escherichia coli, Enterobacter aerogenes, Pseudomonas aeruginosa, Aeromonas hydrophila, Staphylococcus aureus, Streptococcus pyogenes, Aspergillus niger and Candida albicans, The highest zone of inhibition (10-15 mm in diameter) was observed in $100 \mathrm{mg} / \mathrm{ml}$ concentration in all tested microbes [61].The acetone, methanol, ethylacetate extracts $(25-100 \mu \mathrm{g} / \mathrm{ml})$ of Ficus religiosa bark were evaluated for antibacterial activity against Pseudomonas aeruginosa, Escherichia coli, Proteus vulgaris, Bacillus subtilis and Staphylococcus aureus. The growth of Bacillus subtilis was significantly inhibited by acetone extract of Ficus religiosa. Higher concentrations of the same extract were required to inhibit E. coli. Methanol extract of the plant was very active against all the tested bacterial pathogens except $P$. aeruginosa. Ethyl acetate extract was not active against all the bacterial species [57].High antibacterial activity was possessed by aqueous extract of Ficus religiosa against $B$. subtilis with about $24 \mathrm{~mm}$ inhibition zone. It also exerted antibacterial activity against multi drug resistant $P$. aeruginosa [84]. The antiviral activity of Ficus religiosa was investigated against RSV and HRV in vitro by plaque reduction and virus yield assays, and the major mechanism of action was investigated by virus inactivation and time - of - addition assays. Ficus religiosa methanol bark extract was most active against HRV with an $\mathrm{EC}_{50}$ of $5.52 \mu \mathrm{g} / \mathrm{ml}$. This extract inhibited late steps of replicative cycle. Water bark extract was the most active against RSV with an $\mathrm{EC}_{50}$ between 2.23 and $4.37 \mu \mathrm{g} / \mathrm{ml}$. Partial virus inactivation and interference with virus attachment were both found to contribute to the anti-RSV activity. Replication of both viruses was inhibited in viral yield reduction assays [85].The oil leaf of Ficus religiosa was screened for antimicrobial activity against Aspergillus niger, but was inactive $(\mathrm{MIC}=2500 \mu \mathrm{g} / \mathrm{ml})$. The antibacterial effect of leaf oil was studied against Pseudomonas aeruginosa, Bacillus cereus, Staphylococcus aureus, Escherichia coli, and Candida albicans. It was marginally active (MIC $=625 \mu \mathrm{g} / \mathrm{ml})$ [72].

\section{Anti-parasitic effect:}

Ficus religiosa bark methanolic extract showed $100 \%$ lethality for Haemonchus contortus worms using in vitro testing [86].The stem and bark extracts of Ficus religiosa proved lethal to Ascaridia galli in vitro [87].

\section{Anti-Parkinson's activity:}

The anti-Parkinson's activity of petroleum ether extract of Ficus religiosa leaves was investigated in rats. The effects of Ficus religiosa $(100,200$, and $400 \mathrm{mg} / \mathrm{kg}$, po) were studied using in vivo behavioral parameters like catalepsy, muscle rigidity, and locomotor activity and its effects on neurochemical parameters (MDA, CAT, SOD, and GSH) in rats. Haloperidol was used to induce catalepsy and 6 hydroxydopamine (6OHDA) to induce Parkinson's disease-like symptoms. The increased cataleptic scores (induced by haloperidol) were significantly $(\mathrm{p}<0.001)$ reduced by petroleum ether extract of Ficus religiosa at a dose of 200 and $400 \mathrm{mg} / \mathrm{kg}$ (po). 6-OHDA significantly induced motor dysfunction (muscle rigidity and hypolocomotion) and significantly increased lipid peroxidation level and depleted superoxide dismutase, catalase, and reduced glutathione level. Daily administration of petroleum ether extract of Ficus religiosa $(400 \mathrm{mg} / \mathrm{kg})$ significantly improved motor performance and significantly attenuated oxidative damage [58]. 


\section{Anticonvulsant effect:}

The effect of flavonoid-rich ethyl acetate fraction of the crude extract of Ficus religiosa in combined with phenytoin was evaluated on seizure severity, depressive behavior, and cognitive deficit in pentylenetetrazol (PTZ)-kindled mice. Combined treatment of flavonoid-rich ethyl acetate fraction $(2.5,5$, and $10 \mathrm{mg} / \mathrm{kg}$; ip) with a subeffective dose of phenytoin (15 mg/kg; ip) in post kindled animals once daily for fifteen days showed a dosedependent decrease in the seizure severity score, a decreased number of mistakes, increased step-down latency in passive shock avoidance paradigm, and decreased immobility time in the tail suspension test in comparison with the phenytoin only-treated group. Biochemical investigations of the brain tissue showed amelioration of thiobarbituric acid reactive substances, reduced glutathione levels, and reduced catalase and acetylcholinesterase activities [88]. The effect of the saponin-rich fraction of the extract of Ficus religiosa (SRF) was studied in pentylenetetrazol (PTZ) kindling mouse model and its associated depression and cognition deficit. Treatment with the SRF (1, 2 and $4 \mathrm{mg} / \mathrm{kg}$; ip) for 15 days in kindled mice significantly decreased seizure severity on days 5,10 and 15 when challenged with PTZ ( $35 \mathrm{mg} / \mathrm{kg}$; ip). Marked protection against kindling-associated depression was also observed on days 10 and 15 in the SRF-treated groups when tested using the tail-suspension test. The SRF treatment failed to protect kindling-associated learning and memory impairments in the passive shock avoidance paradigm [89]. The anticonvulsant activity of figs extract $(25,50$ and $100 \mathrm{mg} / \mathrm{kg}$, ip) was studied in seizures induced by maximum electroshock (MES), picrotoxin and pentylenetetrazol (PTZ). Cyproheptadine, a nonselective $5 \mathrm{HT}_{1 / 2}$ serotonin antagonist $(4 \mathrm{mg} / \mathrm{kg}$, ip) was used to study the reversal of protective effect of extract in these models. Acute toxicity, neurotoxicity and potentiation of pentobarbitone induced sleep by extract were also studied. Extract showed no toxicity, potentiated pentobarbitone induced sleep and inhibited seizures induced by MES and picrotoxin in a dose dependent manner. Anticonvulsant effect of extract was comparable to clinically used antiepileptic drugs (phenytoin and diazepam). However, PTZ induced seizures were not inhibited. Animals pretreated with cyproheptadine showed inhibition of the anticonvulsant effect of extract which indicated the involvement of serotonergic pathways in the anticonvulsant activity of extract [90].The anticonvulsant activity of the aqueous aerial root extract of Ficus religiosa $(25,50$ and $100 \mathrm{mg} / \mathrm{kg}$, po) was evaluated in chemo-convulsantinduced seizures in mice. The extract protected the animals in the strychnine and pentylenetetrazole tests in a dosedependent manner. It was less potent in the picrotoxin and isoniazid induced seizures tests. The extract also exhibited dose-dependent potentiation of acetylcholine in rat ileum but failed to potentiate the effect of 5-HT in rat fundus strip preparation [91].

\section{Anti-amnesic effect:}

The effect of the methanol extract of Ficus religiosa was investigated in scopolamine-induced anterograde and retrograde amnesia in mice. Transfer latency (TL) to the preferred niche in the elevated plus-maze (EPM) and learning avoidance of passive behavior to avoid punishment in the modified passive avoidance paradigm (MPA) were used as behavioral models for the assessment of memory. Scopolamine (1 mg/kg, ip) was administered before training for induction of anterograde amnesia and before retrieval for induction of retrograde amnesia in both models. The methanol extract of Ficus religiosa $(10,50$, and $100 \mathrm{mg} / \mathrm{kg}$, ip), treatment resulted in significant improvement of memory, as it attenuated the scopolamine-induced anterograde and retrograde amnesia dose-dependently. While, cyproheptadine pretreatment significantly reversed the anti-amnesic effect of the methanol extract of Ficus religiosa [92].Ethanolic extract of Ficus religiosa leaves was evaluated for memory enhancing activities in Wistar albino rats and Swiss albino mice using elevated-plus maze, step through passive avoidance test, sodium nitrite intoxication, Hebb-Williams Maze and radial arm maze. Scopolamine $(1 \mathrm{mg} / \mathrm{kg}$, ip) and sodium nitrite $(95 \mathrm{mg} / \mathrm{kg}$, sc) were used as inducing agent in elevated-plus maze and sodium nitrite intoxication respectively. The extract significantly improved memory and reversed the amnesia induced by scopolamine, and hypoxia induced by sodium nitrite [93].

\section{Acetylcholinestrase inhibitory effect:}

Methanolic extract of the stem bark of Ficus religiosa inhibited the acetylcholinestrase enzyme, accordingly this indicated that the plant was beneficial in Alzheimer's diseases treatment [94].

\section{Hepato-, nephro- and dermato- protective effects:}

The hepatoprotective effect of methanolic extract of Ficus religisoa $(100,200$ and 300mg/kg bw, po) was studied in isoniazid-rifampicin and paracetamol induced hepatotoxicity in rats. All the treatment protocols followed 21 days for INH+RIF model and seven days for paracetamol model. Administration of methanolic extracts of $F$. religisoa significantly prevented isoniazid-rifampicin and paracetamol induced elevation in the levels of serum liver marker enzymes and TBARS level in experimental groups of rats. Total protein and reduced glutathione levels were significantly $(\mathrm{P}<0.001)$ increased in treatment group. The effect of extract was comparable with a standard drug, Liv 52 . The biochemical effects were further confirmed by histological results [95]. 
The hepatoprotective effects of Ficus religiosa latex in cisplatin induced liver injury was investigated in Wistar rats. Cisplatin-treated animals showed significant increase in serum alanine amino transferase, aspartate amino transferase, alkaline phosphatase and hepatocytes cells degeneration, inflammatory infiltrate and necrosis, these changes were significantly $(\mathrm{p}<0.01)$ alleviates by Ficus religiosa latex [56].Alcohol extract of Ficus religiosa stem bark was evaluated for nephro-protective effects, it reduced the blood urea nitrogen level close to normal value against the toxic effects induced by rifampicin and isoniazid in rabbits. The histopathological studies of kidney of untreated rabbit showed severe degree of infiltration in the glomerulus without renal tubular space between the glomerulus, congestion in the renal parenchyma, necrosis and condensed nucleus. The rabbits treated with extract show normal appearance of the nuclei with no condensed nucleus without any necrosis but at some places there was mild congestion. Kidney tubular cells structure was normal in appearance [96].The dermatoprotective effects of ethanolic extract of Ficus religiosa was studied by topical application of te extract to the backs of rabbits daily for 4 days, against known irritants such as sodium dodecyl sulfate, atrazine, and petrol. Skin was examined after 24,48 , and $96 \mathrm{~h}$ for erythema. Skin biopsies were taken on $5^{\text {th }}$ day for microscopic examination. Erythema produced by irritants reduced significantly with the simultaneous application of Ficus religiosa extracts. The mean \pm SEM epidermal thickness (micrometer) with sodium dodecyl sulfate was $45.40 \pm 1.89$ and Ficus religiosa + sodium dodecyl sulfate was $18.60 \pm 0.51$. Similar findings were revealed after using plant extracts with atrazine and petrol. The results indicated that Ficus religiosa demonstrated the potential to block the dermatotoxic effects of topical irritants and could be used successfully to prevent skin toxicity [97].

\section{Antidiabetic effect:}

Aqueous extract of Ficus religiosa at a dose of 100 and $200 \mathrm{mg} / \mathrm{kg}$ orally decreased the fasting blood glucose in streptozotocin induced type 2 diabetic rats. Ficus religiosa modulated the enzymes of antioxidant defence system to combat oxidative stress. As a result, it reduced glutathione (GSH-reduced form) and inhibited the formation of malondialdehyde. Higher dose $(200 \mathrm{mg} / \mathrm{kg})$ had more pronounced effect [98].The hypoglycemic effect of aqueous extract of Ficus religiosa bark at the doses of 25,50 and $100 \mathrm{mg} / \mathrm{kg}$ was studied in normal, glucose-loaded and STZ-diabetic rats. The three doses caused significant reduction in blood glucose levels in both models. The effect was more pronounced in 50 and $100 \mathrm{mg} / \mathrm{kg}$ than $25 \mathrm{mg} / \mathrm{kg}$. The aqueous extract of Ficus religiosa bark also showed significant increase in serum insulin, body weight and glycogen content in liver and skeletal muscle of STZ-induced diabetic rats, with significant reduction in the levels of serum triglyceride and total cholesterol. The aqueous extract of Ficus religiosa bark also showed significant antilipidperoxidative effect in the pancreas of STZ-induced diabetic rats. The antidiabetic effect of Ficus religiosa was comparable with glibenclamide [99] The effect of Ficus religiosa was studied on STZ-induced diabetic cardiomyopathy in rats. Streptozotocin (90 mg/kg i.p.), administered to 2 days old neonates (10-12 g), resulted in significant increase in fasting blood glucose, HbA1c, cardiac hypertrophic index, TGF- $\beta 1$, TNF $\alpha$, malondialdehyde, LDH, CK-MB, BNP and caspase-3. It caused significant reduction in plasma insulin, heart rate and superoxide dismutase. The eightweek treatment of Ficus religiosa started after induction of six weeks of diabetes, significantly improved diabetic markers, oxidative stress, inflammatory and cardiac markers [100]. The effect Ficus religiosa on elevated glucose and inflammatory marker (tumor necrosis factor (TNF- $\alpha$ ) was evaluated in streptozotocin-induce type 2 diabetic rats. Aqueous extract of Ficus religiosa at a dose of 100 and $200 \mathrm{mg} / \mathrm{kg}$ was given orally for a period of 4 weeks. After 4 weeks treatment, fasting blood glucose, postprandial blood glucose and TNF- $\alpha$ in serum were analyzed. Aqueous extract of Ficus religiosa at both dose levels decreased the elevated glucose and TNF- $\alpha$ in type 2 diabetic rats. The extract at $200 \mathrm{mg} / \mathrm{kg}$ had more pronounced effect [101].

\section{Antiinflammatory and analgesic effects:}

The aqueous extract of bark of Ficus religiosa was investigated for its anti-inflammatory effect and for its protective effect on mast cells against degranulation. A significant anti-inflammatory effect was observed in both acute and chronic models of inflammation. The extract also protected mast cells from degranulation induced by various degranulatiors [102]. The effect of a methanol extract of Ficus religiosa leaf was studied in lipopolysaccharide (LPS)-induced production of NO and proinflammatory cytokines, such as tumor necrosis factor-alpha (TNF-alpha), interleukin-beta (IL-1beta) and IL-6 in BV-2 cells, a mouse microglial line. Methanol extract of Ficus religiosa leaf inhibited LPS-induced production of NO and proinflammatory cytokines in a dosedependent manner. Methanol extract of Ficus religiosa leaf also attenuated the expression of mRNA and proteins of inducible nitric oxide synthase (iNOS) and proinflammatory cytokines. The molecular mechanism of methanol extract of Ficus religiosa leaf -mediated attenuation included down-regulation of the extracellular signalregulated kinase (ERK), c-Jun N-terminal kinase (JNK) and p38 mitogen-activated protein kinase (MAPK) signaling pathway, and suppression of the nuclear factor kappaB (NF-kappaB) activation [103]. Different fractions of dried leaves of Ficus religiosa were evaluated for analgesic and anti-inflammatory activity using different models of pain and inflammation. The analgesic activity of Ficus religiosa carried out using acetic acid-induced writhing in mice and tail flick test in rats. The anti-inflammatory activity was evaluated using carrageenan-induced rat paw edema and cotton pellet-granuloma formation in rats. Five different fractions (FRI, FRII, FRIII, FRIV and 
FRV) of Ficus religiosa at the dose level of 20 and $40 \mathrm{mg} / \mathrm{kg}$, po were tested. The fraction FRI (40 mg/kg, po) and FRIII $(40 \mathrm{mg} / \mathrm{kg}$, po) were found to be more effective $(\mathrm{P}<0.01)$ in preventing carrageenan induced rat paw edema, cotton pellet granuloma formation, and acetic acid induced writhing compared to the other fractions. FRI $(20 \mathrm{mg} / \mathrm{kg}$, po) and FRIII (20 mg/kg, po) were also found to be more effective in increasing latency period in tail flick method [104].

\section{Cytotoxic effect:}

F. eligiosa fruit extract demonstrated activity in the brine shrimp test (Artemia salina). F. eligiosa fruit extract exhibited antitumor activity in the potato disc bioassay [105]. Ethanol extracts of the Ficus religiosa was also screened for cytotoxicity activity by using in vivo brine shrimp lethality assay. The percent mortality of shrimp was increased with the increase of the doses of the extracts. $\mathrm{LC}_{50}$ and $\mathrm{LC}_{90}$ values were found to 2.7 and $4.62 \mu \mathrm{g} / \mathrm{ml}$. The oil leaf of Ficus religiosa was marginally active in the brine shrimp lethality test $\left(\mathrm{LC}_{50}=50\right.$ $\mu \mathrm{g} / \mathrm{ml})$ and also showed in vitro cytotoxic activity against MCF-7 human breast tumor cell line (80 $\pm 5 \%$ kill at 100 $\mu \mathrm{g} / \mathrm{ml}$ ) [77]. Extracts showed any marked inhibition on the uptake of calcium into rat pituitary cells GH4C1 [105]. The cytotoxic activity of aqueous and ethanolic preparations of Ficus religiosa bark was evaluated in cervical cancer cell lines, SiHa and HeLa. Both aqueous and ethanolic extracts of the bark showed significant cytotoxicity in cervical cancer cell lines SiHa (HPV16 positive) and HeLa (HPV18 positive) wherein ethanolic extract showed cytotoxicity at much lower doses compared to aqueous extract [62].The anti-neoplastic potential of aqueous extract of Ficus religiosa bark was studied in human cervical cancer cell lines, SiHa and HeLa. The aqueous extract of Ficus religiosa altered the growth kinetics of SiHa (HPV-16 positive) and HeLa (HPV-18 positive) cells in a dose-dependent manner. It blocked the cell cycle progression at G1/S phase in SiHa that was characterized by an increase in the expression of p53, p21 and pRb proteins with a simultaneous decrease in the expression of phospho $\mathrm{Rb}(\mathrm{ppRb})$ protein. In HeLa, aqueous extract of Ficus religiosa induced apoptosis through an increase in intracellular $\mathrm{Ca}^{2+}$ leading to loss of mitochondrial membrane potential, release of cytochrome-c and increase in the expression of caspase-3. The aqueous extract of Ficus religiosa also reduced the migration as well as invasion capability of both cervical cancer cell lines accompanied with down-regulation of MMP-2 and Her-2 expression. In addition, it also reduced the expression of viral oncoproteins E6 and E7 in both cervical cancer cell lines [106]. Different fractions of Ficus religiosa [FR] were tested for in vitro anticancer activity using human

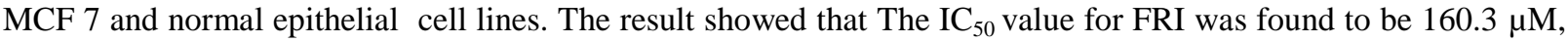
whereas the $\mathrm{IC}_{50}$ value for FRIII was found to be $222.7 \mu \mathrm{M}$ in the normal epithelial cells [107].The potential effect of acetone extract of Ficus religosa leaf (FAE) in multiple apoptosis signaling was studied in human breast cancer cells. FAE treatment significantly induced dose and time dependent, irreversible inhibition of breast cancer cell growth with moderate toxicity to normal breast epithelial cells. Cell cycle analysis showed cell cycle arrest in G1 phase and induction of sub-G0 peak. FAE induced chromatin condensation and displayed an increase in apoptotic population. FAE stimulated the loss of mitochondrial membrane potential in multiple breast cancer cell lines when compared to normal diploid cells. Bax translocation to mitochondria was accompanied by the disruption of mitochondrial membrane potential and marked elevation in LEHDase activity (Caspase 9) [108].

Ficus religiosa leaf extract was proved as a good reducing agent to fabricate silver nanoparticles (AgNPs) by a simple, cost-effective and eco-friendly process in the treatment of Dalton's ascites lymphoma (DAL) in mice model [109].

\section{Anti-ulcer effect:}

Anti-ulcer activity of Ficus religiosa ethanolic extract ( 250 and $500 \mathrm{mg} / \mathrm{kg}$ body weight) was studied on stress induced ulcer animal models. Results showed that the extract treatments reduced ulcer area and gastric secretion in a dose-dependent manner [110]. The anti-ulcer potential of the ethanol extract of leaves of Ficus religiosa was investigated against in vivo aspirin induced ulcer and pylorus ligation assays. Gastric ulcers were induced in Swiss albino rats by oral administration of aspirin suspension and ligate the pylorus part of stomach. The results indicated that ethanolic extract significantly $(\mathrm{p}<0.001)$ decreased the volume of gastric acid secretions, free acidity, total acidity and ulcer index [111].The gastroprotective activity of hydroalcoholic extract leaves of Ficus religiosa was studied at two dose levels $(250$ and $500 \mathrm{mg} / \mathrm{kg}$, oral) in rats against absolute ethanol (0.2 $\mathrm{ml}$ oral), aspirin $(200 \mathrm{mg} / \mathrm{kg})$ and pyloric ligation induced gastric ulcer. Administration of Ficus religiosa to rats significantly decreased the ulcer index value when compared with the control group [112]. The anti-ulcer potential of the ethanol extract of stem bark of Ficus religiosa was evaluated against in vivo indomethacin- and cold restrained stress-induced gastric ulcer, and pylorus ligation assays. The extract (100, $200 \mathrm{and} 400 \mathrm{mg} / \mathrm{kg}$ ) significantly $(\mathrm{P}<0.05)$ reduced the ulcer index in all assays used. The extract also reduced the volume of gastric juice, free and total acidities [113]. 70\% aqueous-ethanol extracts completely inhibited the growth of Helicobacter pylori at $500 \mu \mathrm{g} / \mathrm{ml}$ in all used strains. Anti-H. pylori MBC value ranged from 125 to $250 \mu \mathrm{g} / \mathrm{ml}$ [114]. 


\section{Wound healing effect:}

The wound-healing activity of Ficus religiosa extracts in ointment form (5 and 10\%) was evaluated in incision and excision wound models in Wistar albino rats. Both 5 and $10 \%$ ointments of Ficus religiosa root extracts promoted the wound-healing activity significantly in all the wound models studied. They increased the rate of wound contraction, decreased the period for epithelialisation, increased skin breaking strength and increased hydroxyproline content [115]. The wound healing activity of Ficus religiosa hydroalcoholic leaf extracts ointment (5 and 10\%) was studied in rats using excision and incision wound models. The healing of the wound was assessed by the rate of wound contraction, period of epithelialisation, skin breaking strength. Both (5\% and $10 \%$ ointments) promoted the wound-healing activity significantly in both wound models. High rate of wound contraction, decrease in the period for epithelialisation, high skin breaking strength were observed in animals treated with $10 \%$ leaf extract ointment when compared to the control group of animals [116].

\section{Antioxidant effect:}

The antioxidant potential of aqueous and ethanolic preparations of Ficus religiosa bark was evaluated by oxygen radical absorbance capacity method. The aqueous and ethanolic extracts of the bark exhibited significant total antioxidant capacity, however the aqueous extract showed higher oxygen radical absorbance capacity than ethanolic extract. Both the extracts exhibited a significant increase in anti-lipid peroxidative activity with $\mathrm{IC}_{50}$ values of 29.06 and $34.39 \mu \mathrm{g} / \mathrm{ml}$ for aqueous extract and ethanolic extracts, respectively [62].

\section{Effect on asthma:}

The anti-asthmatic activity of the aqueous extract of Ficus religiosa leaves was evaluated in histamine and acetylcholine induced bronchospasm in guinea pigs. Administration of the aqueous extract of Ficus religiosa leaves $(150$ and $300 \mathrm{mg} / \mathrm{kg}$, ip.) produced significant effect on latency to develop histamine and acetylcholine induced pre-convulsive dyspnea. In the mast cell stabilizing model, the aqueous extract of Ficus religiosa leaves at 10,20 and $30 \mu \mathrm{g} / \mathrm{ml}$ significantly increase the number of intact cells [117].However, in another study, the administration of methanolic extract of Ficus religiosa fruits $(125,250$ and $500 \mathrm{mg} / \mathrm{kg}$, po) did not produced any significant effect on latency to develop histamine induced pre-convulsive dyspnea. While, in a dose of $(0.5,1$ and $2 \mathrm{mg} / \mathrm{ml}$ ), it possessed significant potentiation of the bronchoconstriction induced by both histamine and acetylcholine on guinea pig tracheal chain preparation [75].

\section{Reproductive effects:}

Effects of $1 \%$ methanol extract of Ficus religiosa fruits extract was studied on the goat uterus in vitro in exposure duration dependent manner (1, 4 and 8 hours). Effects on dimensions of uterine glands, surface epithelium, gland cell and myometrium were observed. The treatment induced a decline in uterine glands diameter which were crucial for implantation. The authors concluded that the extract exerted antifertility activity [118]. A clinical trial on 44 patients of erectile dysfunction (ED) were divided into two main groups: diabetic and nondiabetic, and were further divided into two subgroups as trial group and placebo group. In the trial group, Ashvattha prepared with $10 \mathrm{~g}$ powder of Ficus relegiosa root bark, stem bark, fruit and tender leaf buds, was given twice a day. In both the diabetic and the non-diabetic subjects, Ashvattha provided encouraging results on ED as well as on seminal parameters in comparison to the placebo [119].The potential benefits of three different antioxidants in reversing cadmium (Cd)-induced reproductive toxicity was studied in adult male rats. Treated groups received $\mathrm{CdCl}_{2}(0.2 \mathrm{mg} / \mathrm{kg})$, sulforaphane $(25 \mu \mathrm{g} / \mathrm{rat})$, vitamin $\mathrm{E}(75 \mathrm{mg} / \mathrm{kg})$, and Ficus religiosa extract $(100 \mathrm{mg} / \mathrm{kg})$ for 15 days. Cadmium exposure caused significant decrease in final body weight $(\mathrm{p}<0.0001)$. The plasma concentrations of $\mathrm{Cd}$ were significantly increased and $\mathrm{Zn}$ concentration decreased $(\mathrm{p}<0.0001)$ in the $\mathrm{Cd}$ group as compared to the control group. The testicular concentrations of $\mathrm{Cd}$ were significantly increased and $\mathrm{Zn}$ concentration decreased $(\mathrm{p}<0.0001)$ in the $\mathrm{Cd}$ group as compared to the control group. Cadmium exposure caused a significant decrease $(\mathrm{p}<0.0001)$ in plasma testosterone concentrations and daily sperm production as compared to the control group. A significant effects were observed with $\mathrm{Cd}+$ sulforaphane, $\mathrm{Cd}+$ vitamin $\mathrm{E}$, and $\mathrm{Cd}+$ plant extract treated groups in slashing Cd-induced toxicity [120].

\section{Toxicity:}

Administration of $2000 \mathrm{mg} / \mathrm{kg}$ extract did not show any acute toxicity in albino mice 9110, 112].

Orally administered dose ranged from $50-2000 \mathrm{mg} / \mathrm{kg}$ of extract did not produce any significant changes in the autonomic or behavior responses in rats [56].In acute oral toxicity studies, the Ficus religiosa extract treated rats were observed for mortality up to 48 hrs. There was no mortality or any signs of behavioral changes observed after oral administration of methanol extract up to $5000 \mathrm{mg} / \mathrm{kg}$ body weight [95]. 


\section{CONCLUSION:}

The current review highlights the chemical constituents and pharmacological effects of Ficus religiosa as a promising plant for many medical purposes as a results of effectiveness and safety.

\section{REFERENCES:}

[1] Davidson-Hunt I. Ecological ethnobotany: stumbling toward new practices and paradigms. MASA J 2000; 16: 1-13.

[2] Al-Snafi AE. Medicinal plants with anticancer effects (part 2)- plant based review. Sch Acad J Pharm 2016; 5(5): 175-193.

[3] Al-Snafi AE. Antiparasitic, antiprotozoal, molluscicidal and insecticidal activity of medicinal plants (part 2) - plant based review. Sch Acad J Pharm 2016; 5(6): 194-207.

[4] Al-Snafi AE. Medicinal plants with antidiabetic effects (part 2): plant based review. IOSR Journal of Pharmacy 2016; 6(7): 49-61.

[5] Al-Snafi AE. Medicinal plants with antioxidant and FREE radical scavenging effects (part 2): plant based review. IOSR Journal Of Pharmacy 2016; 6(7): 62-82.

[6] Al-Snafi AE. Medicinal plants with antimicrobial activities (part 2): Plant based review. Sch Acad J Pharm 2016; 5(6): 208-239.

[7] Al-Snafi AE. Medicinal plants with cardiovascular effects (part 2): plant based review. IOSR Journal of Pharmacy 2016; 6(7): 43-62.

[8] Al-Snafi AE. Detoxification capacity and protective effects of medicinal plants (part 2): plant based review. IOSR Journal of Pharmacy 2016; 6(7): 63-84.

[9] Al-Snafi AE. Beneficial medicinal plants in digestive system disorders (part 2): plant based review. IOSR Journal of Pharmacy 2016; 6(7): 85-92.

[10] Al-Snafi AE. Immunological effects of medicinal plants: A review (part 2). Immun Endoc \& Metab Agents in Med Chem 2016; 16(2): 100-121.

[11] Al-Snafi AE. Medicinal plants affected male and female fertility (part 1)- A review. IOSR Journal of Pharmacy 2016; 6(10): 11-26.

[12] Al-Snafi AE. Antiparasitic effects of medicinal plants (part 1)- A review. IOSR Journal of Pharmacy 2016; 6(10): 51-66.

[13] Al-Snafi AE. Antimicrobial effects of medicinal plants (part 3): plant based review IOSR Journal of Pharmacy 2016; 6(10): 67-92.

[14] Al-Snafi AE. A review of medicinal plants with broncho-dilatory effect-Part 1. Scholars Academic Journal of Pharmacy, 2015; 5(7): 297-304.

[15] Al-Snafi AE. Medicinal plants with central nervous effects (part 2): plant based review. IOSR Journal of Pharmacy 2016; 6(8): 52-75.

[16] Al-Snafi AE. Adonis aestivalis: pharmacological and toxicological activities- A revew. Asian Journal of Pharmaceutical Science \& Technology 2016; 6(2): 96-102.

[17] Al-Snafi AE. The chemical constituents and therapeutic importance of Cressa cretica- A review. IOSR Journal of Pharmacy 2016; 6(6): 39-46.

[18] Al-Snafi AE. Medical importance of Cichorium intybus - A review IOSR Journal of Pharmacy 2016; 6(3): 41-56.

[19] Al-Snafi AE. The contents and pharmacological importance of Corchorus capsularis- A review. IOSR Journal of Pharmacy 2016; 6(6): 58-63.

[20] Al-Snafi AE. The chemical constituents and pharmacological effects of Convolvulus arvensis and Convolvulus scammonia- A review. IOSR Journal of Pharmacy 2016; 6(6): 64-75.

[21] Al-Snafi AE. Pharmacological and therapeutic importance of Echium italicum- A review. Indo Am J P Sci 2017; 4(02): 394-398.

[22] Al-Snafi AE. Therapeutic importance of Ephedra alata and Ephedra foliata- A review. Indo Am J P Sci 2017; 4(02): 399-406.

[23] Al-Snafi AE. Therapeutic potential of Erodium cicutarium - A review. Indo Am J P Sci 2017; 4(02): 407-413.

[24] Al-Snafi AE. Pharmacology and toxicology of Conium maculatum- A review. The Pharmaceutical and Chemical Journal 2016; 3(2):136-142.

[25] Al-Snafi AE. Therapeutic properties of medicinal plants: a review of plants with hypolipidemic, hemostatic, fibrinolytic and anticoagulant effects (part 1). Asian Journal of Pharmaceutical Science \& Technology 2015; 5(4): 271-284. 
[26] Al-Snafi AE. Pharmacology and therapeutic potential of Euphorbia hirta (Syn: Euphorbia pilulifera) A review. IOSR Journal of Pharmacy 2017; 7(3): 7-20.

[27] Al-Snafi AE. A review on Fagopyrum esculentum: A potential medicinal plant. IOSR Journal of Pharmacy 2017; 7(3): 21-32.

[28] Al-Snafi AE. Nutritional and pharmacological importance of Ficus carica - A review. IOSR Journal of Pharmacy 2017; 7(3): 33-48.

[29] Al-Snafi AE. A review on Erodium cicutarium: A potential medicinal plant. Indo Am J P Sci 2017; 4(01): 110-116.

[30] Al-Snafi AE. Pharmacology of Echinochloa crus-galli - A review. Indo Am J P Sci 2017; 4(01): 117 122.

[31] Al-Snafi AE. The pharmacological potential of Dactyloctenium aegyptium- A review. Indo Am J P Sci 2017; 4(01): 153-159.

[32] Al-Snafi AE. Chemical constituents, pharmacological and therapeutic effects of Eupatorium cannabinum- A review. Indo Am J P Sci 2017; 4(01): 160-168.

[33] Al-Snafi AE. Nutritional and therapeutic importance of Daucus carota- A review. IOSR Journal of Pharmacy 2017; 7(2): 72-88.

[34] Al-Snafi AE. Chemical constituents and pharmacological effects of Dalbergia sissoo - A review. IOSR Journal of Pharmacy 2017; 7(2): 59-71.

[35] Al-Snafi AE. Medical importance of Datura fastuosa (syn: Datura metel) and Datura stramonium - A review. IOSR Journal of Pharmacy 2017; 7(2):43-58.

[36] Al-Snafi AE. A review on Dodonaea viscosa: A potential medicinal plant. IOSR Journal of Pharmacy 2017; 7(2): 10-21.

[37] Al-Snafi AE. The pharmacology and medical importance of Dolichos lablab (Lablab purpureus)- A review. IOSR Journal of Pharmacy 2017; 7(2): 22-30.

[38] Al-Snafi AE. Pharmacological and therapeutic importance of Desmostachya bipinnata- A review. Indo Am J P Sci 2017; 4(01): 60-66.

[39] Al-Snafi AE. Chemical constituents and pharmacological effects of Eryngium creticum- A review. Indo Am J P Sci 2017; 4(01): 67-73.

[40] Al-Snafi AE. The pharmacology of Equisetum arvense- A review. IOSR Journal of Pharmacy 2017; 7(2): 31-42.

[41] Al-Snafi AE. Medicinal plants possessed anti-inflammatory antipyretic and analgesic activities (part 2)plant based review. Sch Acad J Pharm 2016; 5(5): 142-158.

[42] Al-Snafi AE. Medicinal plants affected reproductive systems (part 2) - plant based review. Sch Acad J Pharm 2016; 5(5): 159-174.

[43] Al-Snafi AE. The pharmacological and toxicological effects of Coronilla varia and Coronilla scorpioides: A review. The Pharmaceutical and Chemical Journal 2016; 3(2): 105-114.

[44] Al-Snafi AE. Pharmacological activities of Cotoneaster racemiflorus- A review. The Pharmaceutical and Chemical Journal 2016, 3(2):98-104.

[45] Al-Snafi AE. The chemical constituents and pharmacological activities of Cymbopagon schoenanthus: A review. Chemistry Research Journal 2016; 1(5):53-61.

[46] Al-Snafi AE. Traditional uses, constituents and pharmacological effects of Cuscuta planiflora. The Pharmaceutical and Chemical Journal 2016; 3(4): 215-219.

[47] Al-Snafi AE. The constituents and pharmacology of Cnicus benedictus- A review. The Pharmaceutical and Chemical Journal 2016; 3(2):129-135.

[48] Al-Snafi AE. Medicinal importance of Colchicum candidum- A review. The Pharmaceutical and Chemical Journal 2016; 3(2):111-117.

[49] Al-Snafi AE. Nutritional value and pharmacological importance of citrus species grown in Iraq. IOSR Journal of Pharmacy 2016; 6(8): 76-108.

[50] Al-Snafi AE. Pharmacological activities of Cotoneaster racemiflorus- A review. The Pharmaceutical and Chemical Journal 2016; 3(2): 98-104.

[51] The plant list, a working list of all plant species, Ficus religiosa, http://www. theplantlist.org/tpl/record/kew-2812027.

[52] Sirisha N, Sreenivasulu M, Sangeeta K and Madhusudhana Chetty C. Antioxidant properties of Ficus species - A Review. Int J PharmTech Res 2010; 2(4): 2174-2182.

[53] U.S. National Plant Germplasm System, Ficus religiosa, https://npgsweb.ars-grin. gov/gringlobal/taxonomydetail.aspx?16962

[54] Flora of China, Ficus religiosa, http://www.efloras.org/florataxon.aspx? flora_id= 2\&taxon_id=200006369

[55] Mishra R and Tiwari AK. Preliminary phytochemical screening and HPTLC fingerprinting of fruits of three Ficus species. Journal of Chemical and Pharmaceutical Research, 2013; 5(7):240-245. 
[56] Yadav YC. Hepatoprotective effect of Ficus religiosa latex on cisplatin induced liver injury in Wistar rats. Revista Brasileira de Farmacognosia 2015; 25: 278-283.

[57] Manimozhi DM, Sankaranarayanan S and Sampath Kumar G. Effect of different extracts of stem bark of ficus sp. on multidrug resistant pathogenic bacteria. IJPSR 2012; 3(7): 2122-2129.

[58] Bhangale JO and Acharya SR. Anti-parkinson activity of petroleum ether extract of Ficus religiosa (L.) leaves. Adv Pharmacol Sci 2016; doi: 10. 1155 /2016 / 9436106.

[59] Babu K, Gokul Shankar S and Rai S. Comparative pharmacognostic studies on the barks of four Ficus species. Turkish Journal of Botany 2010; 34(3):215-224.

[60] Jiwala SA, Bagul MS, Parabia M and Rajani M. Evaluation of free radical scavenging activity of an Ayurvedic formulation. Indian Journal of Pharmaceutical Sciences 2008; 70:31-35.

[61] Rajiv P and Sivaraj R. Screeening for phytochemicals and antimicrobial activity of aqueous extract of Ficus religiosa Linn. International Journal of Pharmacy and Pharmaceutical Sciences 2012; 4(5):207209.

[62] Choudhari AS, Suryavanshi S, Ingle H, Kaul-Ghanekar R. Evaluating the antioxidant potential of aqueous and alcoholic extracts of Ficus religiosa using ORAC assay and assessing their cytotoxic activity in cervical cancer cell lines. Biotechnol Bioinf Bioeng 2011; 1(4):443-450.

[63] Sultana B, Anwar F and Ashraf M. Effect of extraction solvent/technique on the antioxidant activity of selected medicinal plant extracts. Molecules 2009; 14: 2167-2180.

[64] Taskeen A, Naeem I, Mubeen H and Mehmood T. Reverse phase high performance liquid chromatographic analysis of flavonoids in two Ficus species. New York Science Journal 2009; 2(5): 32 35.

[65] Makhija IK, Sharma IP and Khamar D. Phytochemistry and pharmacological properties of Ficus religiosa: an overview. Annals of Biological Research 2010; 1: 171-180.

[66] Bagade RJ and Bangale SV. Pharmacological Studies in Ficus religiosa. Int Journal for Pharmaceutical Research Scholars 2015; 4(I-1): 215-223.

[67] Ambika SH, Rao MRR. Studies on a phytosteroin from the bark of Ficus religiosa. Indian Journal of Pharmacy 1967; 29: 91-94.

[68] Husain A, Virmani OP, Popli SP, Misra LN, Gupta MM, Srivastava GN, Abraham Z and Singh AK. Dictionary of Indian medicinal plants. CIMAP, Lucknow- India. 1992: 546.

[69] Swami KD, Malik GS, Bisht NPS. Chemical investigation of stem bark of Ficus religiosa and Prosopis spicigera. Journal of the Indian Chemical Society 1989; 66: 288-289.

[70] Ali M and Qadry JS. Amino acid composition of fruits and seeds of medicinal plants. J Indian Chem Soc 1987; 64:230-231.

[71] Grison-Pigé L, Hossaert-McKey M, Greeff JM and Bessière JM. Fig volatile compounds- a first comparative study. Phytochemistry 2002;61(1):61-71.

[72] Poudel A, Satyal P and Setzer WN. Composition and bioactivities of the leaf essential oil of Ficus religiosa Linn. American Journal of Essential Oils and Natural Products 2015; 2 (3): 16-17.

[73] Panda SK, Panda NC and Sahue BK: Phytochemistry and pharmacological properties of Ficus religiosa: An overview. Indian Veterinary Journal 1976; 60:660-664.

[74] Verma RS and Bhatia KS. Chromatographic study of amino acids of the leaf protein concentrates of Ficus religiosa Linn. and Mimusops flengi Linn. The Indian Journal of Hospital Pharmacy 1986; 23:231-232.

[75] Ahuja D, Bijjem KR and Kalia AN. Bronchospasm potentiating effect of methanolic extract of Ficus religiosa fruits in guinea pigs. J Ethnopharmacol 2011; 133(2): 324-328.

[76] Kumari M, Sharma A and Jagannadham MV. Decolorization of crude latex by activated charcoal, purification and physico-chemical characterization of religiosin, a milk-clotting serine protease from the latex of Ficus religiosa. J Agric Food Chem 2010; 58(13): 8027-8034.

[77] Rahman M, Khatun A, Khan S, Hossain F and AKhan A. Phytochemical, cytotoxic and antibacterial activity of two medicinal plants of Bangladesh. Pharmacology Online 2014; 4: 3-10.

[78] Blesson J, Sebastian J, Chinju AR, Saji CV, Pillai DV, Manohar G and Jose G.South Indian plants Lawsonia inermis L., Ocimum sanctum L., Ficus religiosa L. and Callistemon citrinus L. exhibit antibiotic resistance modifying effect on native strain of Staphylococcus aureus. Int. Journal of Applied Sciences and Engineering Research 2014; 3(4): 869-878.

[79] Uma B, Prabhakar K and Rajendran S. In vitro antimicrobial activity and phytochemical analysis of Ficus religiosa L. and Ficus bengalensis L. against diarrhoeal enterotoxigenic E. coli. Ethnobotanical Leaflets 2009; 13: 472-474.

[80] Pawar PL and Nabar BM. Effect of plant extracts formulated in different ointments. Indian Journal of Pharmaceutical Sciences 2010: 397-401. 
[81] Kaur R, Goyal AK, Kaushik D and Sharma RK. In vitro studies on antibiotic activity of Ficus religiosa fruits extract against human pathogenic bacteria. Journal of Chemical and Pharmaceutical Research 2014; 6(11): 80-84.

[82] Sharma H, Yunus GY, Mohapatra AK, Kulshrestha R, Agrawal R and Kalra M. Antimicrobial efficacy of three medicinal plants Glycyrrhiza glabra, Ficus religiosa, and Plantago major on inhibiting primary plaque colonizers and periodontal pathogens: An in vitro study. Indian J Dent Res 2016; 27(2): 200-204.

[83] Ramakrishnaiah G and Hariprasad T. In vitro antimicrobial activity of leaves and bark extracts of Ficus religiosa (Linn.). Indian Journal of Pharmaceutical and Biological Research 2013; 1(1): 37-42.

[84] Preethi R, Devanathan VV and Loganathan M. Antimicrobial and antioxidant efficacy of some medicinal plants against food borne pathogens. Advances in Biological Research 2010; 4:122-125.

[85] Cagno V, Civra A, Kumar R, Pradhan S, Donalisio M, Sinha BN, Ghosh M and Lembo D. Ficus religiosa L. bark extracts inhibit human rhinovirus and respiratory syncytial virus infection in vitro. J Ethnopharmacol 2015;176:252-257.

[86] Iqbal Z, Nadeem QK, Khan MN, Akhtar MS and Waraich FN. In vitro anthelmintic activity of Allium sativum, Zingiber officinale, Curcurbita mexicana and Ficus religiosa. Int J Agr Biol 2001; 3: 454-457.

[87] De Amorin A, Borba HR, Carauta JP, Lopes D and Kaplan MA. Anthelmintic activity of the latex of Ficus species. J Ethnopharmacol 1999; 64:255-258.

[88] Singh P, Singh D and Goel RK. Ficus religiosa L. figs - a potential herbal adjuvant to phenytoin for improved management of epilepsy and associated behavioral comorbidities. Epilepsy Behav 2014;41:171-178.

[89] Singh D, Mishra A and Goel RK. Effect of saponin fraction from Ficus religiosa on memory deficit, and behavioral and biochemical impairments in pentylenetetrazol kindled mice. Epilepsy Behav 2013; 27(1): 206-211.

[90] Singh D and Goel RK. Anticonvulsant effect of Ficus religiosa: role of serotonergic pathways. J Ethnopharmacol 2009; 123(2): 330-334.

[91] Patil MS, Patil CR, Patil SW and Jadhav RB. Anticonvulsant activity of aqueous root extract of Ficus religiosa. J Ethnopharmacol 2011; 133(1):92-96.

[92] Kaur H, Singh D, Singh B and Goel RK. Anti-amnesic effect of Ficus religiosa in scopolamine-induced anterograde and retrograde amnesia. Pharm Biol 2010; 48(2): 234-240.

[93] Devi WB, Sengottuvela S, Haja SS, Lalitha V and Sivakumar T. Memory enhancing activities of Ficus religiosa leaves in rodents. International Journal of Research in Ayurveda and Pharmacy 2011; 2(3): 834838.

[94] Panchawat S. Ficus religiosa Roxb.(Peepal): A phyto-pharmacological review. International Journal of Pharmaceutical and Chemical Sciences 2012; 1(1): 435-446.

[95] Parameswari SA, Chetty CM and Chandrasekhar KB. Hepatoprotective activity of Ficus religiosa leaves against isoniazid+rifampicin and paracetamol induced hepatotoxicity. Pharmacognosy Res 2013; 5(4): 271-276.

[96] Hashmi N, Muhammad F, Javed I, Khan JA, Khan MZ, Khaliq T and Aslam B. Nephroprotective effects of Ficus religiosa Linn (peepal plant) stem bark against isoniazid and rifampicin induced nephrotoxicity in albino rabbits. Pak Vet J 2013; 33(3): 330-334.

[97] Waheed M, Muhammad F, Javed I, Akhtar M, Saleemi MK, Khaliq T, Awais MM and Anwar MI. Dermatoprotective effects of some plant extracts (genus Ficus) against experimentally induced toxicological insults in rabbits. Toxicol Ind Health 2015; 31(11): 982-989.

[98] Kirana H, Agrawal SS and Srinivasan BP. Aqueous extract of Ficus religiosa Linn. reduces oxidative stress in experimentally induced type 2 diabetic rats. Indian J Exp Biol 2009; 47(10): 822-826.

[99] Pandit R, Phadke A and Jagtap A. Antidiabetic effect of Ficus religiosa extract in streptozotocininduced diabetic rats. J Ethnopharmacol 2010; 128(2):462-466.

[100] Sharma R, Kumar A, Srinivasan BP, Chauhan A and Dubey K. Cardioprotective effects of Ficus religiosa in neonatal streptozotocin-induced diabetic cardiomyopathy in rats. Biomedicine \& Aging Pathology 2014; 4(1): 53-58.

[101] Kirana H, Jali MV and Srinivasan BP. The study of aqueous extract of Ficus religiosa Linn. on cytokine TNF- $\alpha$ in type 2 diabetic rats. Pharmacognosy Res 2011; 3(1): 30-34.

[102] Viswanathan S, Thirugnanasambantham P, Reddy MK, Narasimhan S and Subramaniam GA. Antiinflammatory and mast cell protective effect of Ficus religiosa. Anc Sci Life 1990; 10(2): 122-125.

[103] Jung HW, Son HY, Minh CV, Kim YH and Park YK. Methanol extract of Ficus leaf inhibits the production of nitric oxide and proinflammatory cytokines in LPS-stimulated microglia via the MAPK pathway. Phytother Res 2008; 22(8): 1064-1069.

[104] Gulecha V, Sivakumar T, Upaganlawar A, Mahajan M and Upasani C. Screening of Ficus religiosa leaves fractions for analgesic and anti-inflammatory activities. Indian J Pharmacol 2011;43(6):662-666. 
[105] Mousa O, Vuorela P, Kiviranta J, Wahab SA, Hiltunen R and Vuorela H. Bioactivity of certain Egyptian Ficus species. J Ethnopharmacol 1994;41(1-2):71-76.

[106] Choudhari AS, Suryavanshi SA and Kaul-Ghanekar R. The aqueous extract of Ficus religiosa induces cell cycle arrest in human cervical cancer cell lines SiHa (HPV-16 Positive) and apoptosis in HeLa (HPV-18 positive). PLoS One 2013; 8(7): e70127.

[107] Gulecha V and Sivakuma T. Anticancer activity of Tephrosia purpurea and Ficus religiosa using MCF 7 cell lines. Asian Pac J Trop Med 2011; 4(7): 526-529.

[108] Haneef J, Parvathy M, Thankayyan R SK, Sithul H and Sreeharshan S. Bax translocation mediated mitochondrial apoptosis and caspase dependent photosensitizing effect of Ficus religiosa on cancer cells. PLoS One 2012; 7(7): e40055.

[109] Antony JJ, Sithika MAM, Joseph TA, Suriyakalaa U, Sankarganesh A, Siva D, Kalaiselvi S and Achiraman S. In vivo antitumor activity of biosynthesized silver nanoparticles using Ficus religiosa as a nanofactory in DAL induced mice model. Colloids and Surfaces B: Biointerfaces 2013;108: 185-190.

[110] Gregory M, Divya B, Mary RA, Viji MM, Kalaichelvan VK and Palanivel V. Anti-ulcer activity of Ficus religiosa leaf ethanolic extract. Asian Pac J Trop Biomed 2013; 3(7): 554-556.

[111] Kumar H, Srivastava SK, Rao SV and Yadav S. Anti-ulcer activity of Ficus religiosa L. leaves on experimental animals. International Journal of Pharmaceutical Sciences Review and Research 2011; 11(2): 83-86.

[112] Saha S and Goswami G. Study of anti ulcer activity of Ficus religiosa L. on experimentally induced gastric ulcers in rats. Asian Pacific Journal of Tropical Medicine 2010: 791-793.

[113] Ali Khan MS, Hussain SA, Jais AMM, Zakaria ZA and Khan M. Anti-ulcer activity of Ficus religiosa stem bark ethanolic extract in rats. Journal of Medicinal Plants Research 2011; 5(3): 354-359.

[114] Zaidi SFH, Yamadab K, Kadowakia M, Usmanghanic K and Sugiyamab T. Bactericidal activity of medicinal plants, employed for the treatment of gastrointestinal ailments, against Helicobacter pylori. J Ethnopharmacol 2009; 121:286-291.

[115] Murti K, Lambole V, Gajera V and Panchal M. Exploration of healing promoting potentials of roots of Ficus religiosa. Pharmacologia 2011; 2: 374-378.

[116] Roy K, Shivakumar H and Sarkar S. Wound healing potential of leaf extracts of Ficus religiosa on Wistar albino strain rats. International Journal of PharmTech Research 2009;1(3): 506-508.

[117] Kapoor M, Jasani N, Acharya N, Acharya S and Kumar V. Phytopharmacological evaluation and antiasthmatic activity of Ficus religiosa leaves. Asian Pac J Trop Med 2011; 4(8):642-644.

[118] Goyal AK. Phytochemistry and in vitro studies on anti-fertility effect of Ficus religiosa fruits extract on uterine morphology of goat (Capra hircus). International Journal of Drug Development \& Research 2014; 6(2):141-158.

[119] Virani NV, Chandola HM, Vyas SN and Jadeja DB. Clinical study on erectile dysfunction in diabetic and non-diabetic subjects and its management with Ficus relegiosa Linn. Ayu 2010;31(3):272-279.

[120] Jahan S, Khan M, Ahmed S and Ullah H. Comparative analysis of antioxidants against cadmium induced reproductive toxicity in adult male rats. Syst Biol Reprod Med 2014; 60(1): 28-34. 